\title{
IDEAL PERSONAL COMPETENCY BASED ON ISEN MULANG'S DAYAK PHILOSOPHY
}

\author{
Dody Riswanto ${ }^{1}$, Ade Hidayat
}

\begin{abstract}
The purpose of this study was to find the ideal personal values of the counselor based on the isen mulang philosophy of the Dayak tribe. The research method used is qualitative where researchers act as key instruments, data collection techniques are interviews, observation and documentation studies. The results of the study are that the isen mulang philosophy contains four main values, namely the value of struggle, the value of heroism, the value of sacrifice, and the value of spirit never giving up. The four elements of the isen mulang values are implemented by counselors in everyday life to form an ideal personal competence of the counselor.
\end{abstract}

Keywords: Competence, Personal, Counselor, Isen Mulang, Dayak Tribe

JOMSIGN: Journal of Multicultural Studies in Guidance and Counseling Website: http://ejournal.upi.edu/index.php/JOMSIGN

Permalink: http://ejournal.upi.edu/index.php/JOMSIGN/article/view/6314

How to cite (APA): Riswanto, D., \& Hidayat, A. (2019). Ideal Personal Competency Based on Isen Mulang's Dayak Philosophy. JOMSIGN: Journal of Multicultural Studies in Guidance and Counseling, 3(1), 27-34

\section{INTRODUCTION}

Counselors are teachers who have the task of carrying out guidance and counseling services in schools, counselors carry out tasks professionally based on the rules, principles and skills and competencies that support their main tasks, among the competencies that must be possessed by counselors are personality competencies, in accordance with the mandate Minister of National Education Regulation number 27 of 2008 concerning standards of academic qualifications and counselor competencies where one of the articles mentions personal counselor competencies.

Counselor's personal competencies include conformity to the cultures adopted by the local community, the counselor is able to harmonize personality with cultural understandings embraced by the community where the counselor is on duty and serves as a guidance and counseling teacher in school while continuing to uphold the principles of the belief held by a counselor.

\footnotetext{
${ }^{1}$ Universitas Mathla'ul Anwar Banten; ronaldody32@gmail.com
} 
Cross-cultural understanding that needs to be interpreted by a counselor is how the counselor is able to socially and culturally follow the local culture to further take the 'fibers of meaning' from the local wisdom of the local community to be further implemented and interpreted comprehensively with the aim that local wisdom can become a local wisdom the values adopted by the counselor become a personal competence that harmonizes with the sociocultural local community.

Cross-cultural understanding is carried out by the counselor to fit the values shared by students or counselees at school, with the aim that it does not cause cultural conflict which could one day lead to disputes that lead to disputes resulting from 'cultural friction' that is not harmonious between counselor with students at school.

Multicultural understanding needs to be understood by the counselor as part of personality competence, through habituation and by learning the local socio-cultural local wisdom, based on a belief that these values are the ideal form that can be realized and implemented by the counselor through attitudes and personality in everyday life.

The values of local wisdom that can be adhered by counselors to form ideal personalities are local wisdom owned by the Dayak tribes of Central Kalimantan, one of which is the philosophy of Isen Mulang, which has a deep meaning and contains elements of personality values that can be taken by counselor as an ideal form of personality competency value.

The mandate of the Minister of National Education Regulation No. 27/2008 regarding the standard of academic qualifications and counselor competence states that one of the counselor competency items is personality competency where several items in personality competency read about respecting and upholding human values, individuality and freedom of choice which are explicitly multiculturalism charged where the counselor must uphold human values, and the individuality of the counselee in this case where the counselee lives in accordance with the cultural perspective of the counselee or students.

Personality counselor competence is closely related to the perspective of multiculturalism. According to Maria et al (2017), personality competence is explicitly loaded with multicultural elements related to tolerance of followers of other religions, sensitivity to diversity, and respect for diversity (more on the counselee's side). The meaning that can be drawn from the opinion of Maria et 
al is that discussing the personal competence of the counselor is closely related to the multiculturalism element, containing an element of sensitivity to diversity which in this case the counselor must be sensitive to Dayak culture especially the philosophy of isen mulang and respect for diversity especially diversity on the counselee party is mostly ethnic Dayak.

According to Dodson (2013) Counselors should be encouraged to directly challenge their views on race and ethnicity, and to consider how their views are formed through their own experiences. After school counselors have a better understanding of multicultural counseling, school counselors can work with administrators to incorporating multiculturalism in all aspects of school culture.

The results of research on the personality competency of counselors have been conducted such as surveys of counselors in junior high schools and equivalent in Citeureup sub-district, according to Dewi Sapto et al (2016) explaining that the personality competencies of counselors in junior high schools in Citeureup sub-district are in the competent category of 26 people (26 people) $76.5 \%$ ), which means that most counselors have been able to display the ideal personality as a teacher of guidance and counseling at school.

According to Amallia (2016) ideally a counselor is able to actualize himself to be a wise person and humanistic oriented, who cares about the demands of the profession, personality is not only formed solely because of experience but is an integrity of the will and ability to be able to behave and act as a professional counselor. The meaning that can be drawn from the information is that the counselor is expected to actualize himself to be a wise and humanistic-oriented person, wise to cultural awareness based on the culture in which the counselor lives and is able to absorb humanistic values.

According to Riswanto et al (2017) counselors must have a strong multicultural awareness and a deep understanding of cultural principles, this will realize the competency of counselors who are aware of culture, multicultural competence in counselors is considered to have an important role in carrying out duties as a counselor in schools, namely by understanding the characteristics or cultural patterns of the Dayak tribe in Central Kalimantan.

Isen Mulang, in general, can be interpreted to mean unyielding, refusing to surrender, undaunted progress or words with terms that have the same meaning as that understanding, according to Kusni Sulang (2010) Isen Mulang as a discourse containing meaning will never go home if does not win, the interpretation is that once the Dayak tribe decides to fight on the battlefield of 
battle, it is very shameful to go home without bringing a victory, because it is better to go home in name (to die) than to go home to bear defeat. For anyone who goes home with a loss, the person concerned will not have a place or dignity before the community. Kusni Sulang (2010) stated that symbolically, the views and attitudes of Isen Mulang were expressed with a bulb or red headband, even or plot, isen mulang as a part of the order of values about a dream man.

According to Imam Qalyubi et al (2018) defines that culture has a major role in encouraging discourses in the movement of the capital, especially in aspects of the spirit of Isen Mulang that has been united in the Dayak community, even the symbol of Isen Mulang itself has become the motto of the Central Kalimantan provincial government as a form of spirit Dayak community in developing their territory. The spirit of Isen Mulang is a value system that has been inherited by Dayak community anchors to date.

\section{METHODS}

The research method used in this study is a qualitative approach, according to Jonker et al (2011) qualitative research serves to identify the characteristics and structure of phenomena and events in their natural context. Muhammad (2011) defines that qualitative research aims to understand social phenomena holistically and explore deeper and deeper insights. Data collection techniques used were interviews, observation or documentation study and triangulation of data, researchers played a key instrument, the location of the study was the city of Palangkaraya, Central Kalimantan.

The interview technique was carried out using structured interviews where the researcher already knew what information would be obtained and prepared written questions in the interview guidelines, observations were carried out in Palangkaraya city, the reason for making Palangkaraya city as a field observation was because Palangkaraya city was a meeting of various kinds of existing cultural currents. in Central Kalimantan and is the main axis of traditional and modern cultural encounters so that it allows researchers to describe field phenomena more naturally and accurately.

Documentation study is carried out by adopting various kinds of scientific writings related to the research topic and recording the results of interviews as physical evidence, triangulation of data is a process of checking the validity of selected data accurately through checking and comparing various types of data for further selection and presentation become primary data or main data. 
Data triangulation is carried out by first selecting which data are considered primary and primary, then subsequently combined into a valid data validity, interviews are conducted with informants tested from various selected informants, namely the head of the Dayak traditional council Sabran Achmad and the informant from academics namely Prof. Drs. Kumpiady Widen, P.hD, the selection of informants largely determines the final results of the study, for that triangulation of data in the selection of informants is adapted from a variety of choices to produce valid primary data.

\section{RESULTS AND DISCUSSIONS}

Isen Mulang contains 4 elements of personality values, namely the values of struggle, the values of heroism, the values of sacrifice, and the values of the spirit of not giving up, these 4 elements of value can be taken by counselors to form a characteristic of values ideal personality that can be implemented in everyday life, forming a multicultural competency in the counselor's personal, which adapts to the current development of the times.

The values of struggle in Isen Mulang contain a meaning that the struggle that is carried out continuously can lead to brilliant results that impact on a victory that spawned the meaning of success after continuously struggling with various obstacles and risks that must be passed, this victory is the core meaning of the values of the struggle by first battling against the enemy even though no matter how heavy the obstacles and risks faced.

The values of heroism in Isen Mulang contain a meaning that it is better to die on the battlefield than to surrender to the enemy and go home with humiliation and misery of defeat, the meaning of heroism is only 2 choices when the Dayak tribe fought on the battlefield, won or won defeat with the risk of defeat is unavoidable, then keep fighting until the last point of death, the values of heroism deserve to be pinned on him even though victory cannot be achieved.

The values of sacrifice in Isen Mulang implies that Dayak Fighters fight with enemies at the expense of all they have, by leaving children and wives, parents and property to be together with other Dayak fighters on the battlefield, the values of sacrifice contains the principles of solidarity, brotherhood, solidarity and a sense of belonging and sharing with others.

The values of the spirit of not giving up on Isen Mulang implies that it is never to give up no matter how heavy the enemy they face, which is also known 
as ela mikeh, the spirit that never subsides and the attitude of refusing to surrender with various obstacles that are difficult to face, do not retreat or surrender in war if we are involved in it, therefore the symbol embraced in the battle is mamut menteng, or brave knight, if the mamut menteng symbol has been engraved in the souls of Dayak warriors, then the spirit of not giving up in conquering the enemy is always brave always present and will never subside even though the enemy faced is very heavy and difficult to defeat.

Personal values that can be adhered to by the counselor from the meaning of the value of the struggle of the philosophy of Isen Mulang are the values of victory even though they have to go through tough and difficult obstacles and problems, the values of struggle teach the counselor not to despair, to continue to be positive and dare to try to do the latest creativity and innovation, failure does not make counselors inferior and feel isolated from the school environment, but instead becomes a motivation that forms a positive mentality, which leads to a victory that will be achieved by the counselor in the future.

Personal values that can be adhered to by a counselor from the meaning of the heroic values of the philosophy of Isen Mulang are exemplary values, how a counselor should be an example for students in school, how counselors teach students to succeed in achieving their goals with motivation -motivation and positive suggestions that can make students confident, counselors as role models for students who teach that victory in achieving success must be achieved in the future with the principles of example and heroism.

Personal values that can be adhered to by a counselor from the meaning of the value of sacrifice from the philosophy of Isen Mulang is the fulfillment of the counselor's skill and scientific competence with various sacrifices made by the counselor, the sacrifice of the counselor to demand guidance and counseling at the first, master or doctoral level, the sacrifice of counselors to attend training that hones skills, the sacrifice of counselors both morally and materially carry out the task of providing guidance and counseling in schools and to the general public, the results of which can be useful and efficient for the environment.

Personal values that can be adhered to by a counselor from the meaning of the unrelenting spirit of Isen Mulang's philosophy is optimism to continue to work and work professionally by prioritizing the principle that there is never a failure in carrying out the task, the values contained therein are teaching the counselor to continue to work professionally and continue to work without ever 
thinking about a failure, a failure will not be realized if the counselor is always optimistic and has a spirit of not giving up.

Isen Mulang's philosophy contains meaningful values of struggle, heroism, sacrifice and the spirit of never giving up, which in ancient times was aimed at when Dayak forces fought against the enemy, therefore the spirit of Isen Mulang in the modern era can be applied by educators one of them by the counselor where one of the main tasks of the counselor is to serve the developmental tasks of the counselee or students at school, therefore multicultural understanding is needed in this case to avoid cultural contact, especially for counselors who have cultural differences with the counselee or school students.

Isen Mulang's philosophical values which contain 4 elements are fully embraced by the counselor to form an ideal personality characteristic for the counselor, counselor with the soul of Isen Mulang, a counselor who understands and values social and multicultural values, a successful counselor and high integrity who uphold the local wisdom values of the Dayak tribes of Central Kalimantan.

\section{CONCLUSIONS}

The values contained in the philosophy of Isen Mulang consist of 4 parts, the first is the value of struggle, the value of heroism, the value of sacrifice, and the value of relentless enthusiasm, all of these values are combined into a unified whole that forms the values of personality that the ideal that can be implemented by the counselor into a personality competency in its application in everyday life, consciously cultured, aware that the professional ethics of the counselor is to understand multiculturalism so as to realize the ideal personality competency of the counselor who understands the meaningfulness of Isen Mulang's philosophy.

\section{REFERENCES}

Dodson, Fallon K. (2013). Exploring the Multicultural Competence of School Counselors. The Journal of Counselor Preparation and Supervision: Volume 5 Number 2, Page 18-29

Hastuti, Maria Margaretha Sri \& Marheni, Krisna Indah. (2017). Proceeding Seminar dan Lokakarya Nasional Revitalisasi Laboratorium dan Jurnal 
Ilmiah Dalam Implementasi Kurikulum Bimbingan dan Konseling Berbasis KKNI. Malang.

Jonker, Jan. Pennink, Bartjan J.W. Wahyuni, Sari. (2011). Metodologi Penelitian: Panduan untuk Master dan Ph.D di Bidang Manajemen. Salemba Empat: Jakarta

Muhammad. (2011). Metode Penelitian Bahasa. Ar-Ruzz Media. Sleman, Jogjakarta

Peraturan Menteri Pendidikan Nasional Republik Indonesia Nomor 27 Tahun 2008 Tentang Standar Kualifikasi Akademik dan Kompetensi Konselor.

Putri, Amallia. (2016). Pentingnya Kualitas Pribadi Konselor dalam Konseling Untuk Membangun Hubungan Antar Konselor dan Konseli. Jurnal Bimbingan Konseling Indonesia: Volume 1 Nomor 1 Maret 2016, 10-13.

Qalyubi, I., Qodir, A., \& Abubakar. (2018). International Seminar On Recent Language, Literature, And Local Culture Studies (BASA 2018): "Isen Mulang" Motto : Spirit Symbol of the Dayak Community in Response to Capital City Movement to Palangka Raya. Advances in Social Science, Education and Humanities Research, Volume 280

Riswanto, D., Mappiare-AT, A., \& Irtadji, M. (2017). Kompetensi Multikultural Konselor Pada Kebudayaan Suku Dayak Kalimantan Tengah. JOMSIGN: Journal of Multicultural Studies in Guidance and Counselling: Volume 1 Nomor 2, September 2017, 215-226.

Sulang, Kusni. (2010). Jurnal Toddoppuli: Apa Arti Isen Mulang. Jurnal toddoppuli. wordpress. com/?s=arti+isen+mulang\&submit=search 